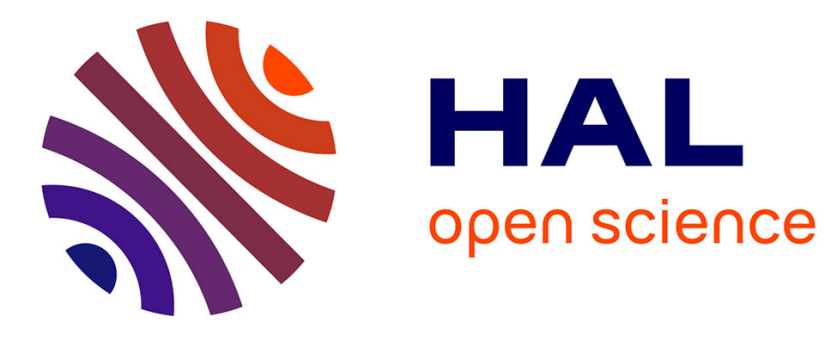

\title{
Abnormal inspiratory depth in Phox2a haploinsufficient mice.
}

\author{
Ludovic Wrobel, M. Ogier, Fabrice Chatonnet, Sandra Autran, Valérie \\ Mézières, Muriel Thoby-Brisson, Heather Mclean, C. Taeron, Jean \\ Champagnat
}

\section{To cite this version:}

Ludovic Wrobel, M. Ogier, Fabrice Chatonnet, Sandra Autran, Valérie Mézières, et al.. Abnormal inspiratory depth in Phox2a haploinsufficient mice.. Neuroscience, 2007, 145 (1), pp.384-92. 10.1016/j.neuroscience.2006.11.055 . hal-00151750

\section{HAL Id: hal-00151750 https://hal.science/hal-00151750}

Submitted on 6 Jun 2007

HAL is a multi-disciplinary open access archive for the deposit and dissemination of scientific research documents, whether they are published or not. The documents may come from teaching and research institutions in France or abroad, or from public or private research centers.
L'archive ouverte pluridisciplinaire HAL, est destinée au dépôt et à la diffusion de documents scientifiques de niveau recherche, publiés ou non, émanant des établissements d'enseignement et de recherche français ou étrangers, des laboratoires publics ou privés. 
This article has been published in Neuroscience, 2007, 145(1), pp. 384-392

doi: 10.1016/j.neuroscience.2006.11.055 ; Elsevier

The publication is available online at

http://www.sciencedirect.com

\title{
Abnormal inspiratory depth in Phox2a Haploinsufficient Mice
}

\author{
Wrobel, L.J. ${ }^{1}$, Ogier, M. ${ }^{1,2}$, Chatonnet F. ${ }^{1,3}$, Autran, S. ${ }^{1}$, Mézières, . $^{1}$, Thoby-Brisson, M. ${ }^{1}$, \\ McLean H., Champagnat, J. ${ }^{1}$
}

Present adress :

${ }^{1}$ Neurobiologie génétique et intégrative, UPR2216 CNRS, 1 avenue de la terrasse, 91198 Gif sur Yvette, France.

${ }^{2}$ Department of Neurosciences, Case Western Reserve University - School of Medicine, 10900 Euclid Avenue, Cleveland, OH 44106, USA.

${ }^{3}$ present address: Cellular and Molecular Biology Dept, Karolinska Institute, 17177

Stockholm, Sweden.

Corresponding author:

Wrobel Ludovic J.

Neurobiologie génétique et intégrative, UPR2216 CNRS

1 avenue de la terrasse, 91198 Gif sur Yvette, France

e-mail adress : wrobel@inaf.cnrs-gif.fr

\begin{abstract}
Mutations of genes encoding Phox2a or Phox2b transcription factor induce modifications of different brainstem neuronal networks. Such modifications are associated with defects in the breathing behaviour at birth. In particular, an abnormal breathing frequency is observed in Phox $2 a^{---}$mutant mice, resulting from abnormal development of the locus coeruleus nucleus. However, the role of Phox2a proteins in the establishment of cardiorespiratory neuronal pathways is unknown, largely because mutants die shortly after birth. In the present study, we examined the effects of a haploinsufficiency of the Phox2a gene. Phox2a heterozygotes survive and exhibit a significantly larger inspiratory volume and a delayed inspiratory duration compared to wild-type animals during both normoxic breathing and in response to hypoxia. This phenotype accompanied by an unaltered frequency is evident at birth and persists until at least postnatal day 10. Morphological analysis of $P$ hox $2 a^{+/-}$animals reveal no anomaly in the locus coeruleus region, but highlighted an increase in the number of cells expressing the catecholamine-synthesizing enzyme tyrosine hydroxylase, a marker of chemoafferent neurons, in the petrosal sensory ganglion. These data indicate that Phox2a plays a critical role in the ontogeny of the reflex control of inspiration.
\end{abstract}

Keywords: Breathing, neonate, petrosal ganglion, brainstem. 
Pulmonary ventilation adequately adapts to physiological and environmental changes to meet the organism's needs in oxygen by the combined activity of brainstem central pattern generators (CPG) and peripheral reflexes controlling lung inflation and blood gases level. The neural output of the CPG intermittently activates the inspiratory muscles at a defined frequency (Smith et al. 1991, Bianchi et al., 1995, Hilaire and Duron, 1999, Thoby-Brisson and Ramirez, 2000, Richter and Spyer, 2001, Onimaru and Homma, 2003; Feldman and Del Negro, 2006). Lung inflation is monitored by stretch receptors that activate the Hering-Breuer reflex to immediately adjust breathing amplitude (tidal volume: VT) and inspiratory duration (Ti) (Duara et al., 1991, 1993, Bianchi et al., 1995). The adequacy of pulmonary ventilation is monitored by chemoceptors sensing levels of oxygen and carbon dioxide allowing the proper matching of ventilation to metabolism and for responses to environmental changes such as hypoxia (Neubauer et al., 1990, Dillon et al., 1991, Rigatto et al., 1998, Roux et al., 2000; Pascual et al., 2002). Investigations on human breathing dysfunctions show a particular role of peripheral reflexes in controlling breathing activity (Dauger et al. 2003). However, in vivo breathing patterns resulting from the impaired development of peripheral reflexes remain quite unknown. To this end we investigated mutations affecting afferent neurons in the distal sensory ganglia of the ninth and tenth cranial nerves (petrosal and nodose ganglia respectively) and particularly the subpopulation of chemoafferent cells expressing Tyrosine Hydroxylase $(\mathrm{TH})$ in the petrosal ganglia.

It appears that developmental genes such as Phox 2 paralogs may be responsible for reflex arches set up and for unconscious breathing control (Amiel et al. 2003; de Pontual et al. 2003). Phox2 is a family of homeodomain transcription factors that includes two paralogs, Phox2a and Phox2b, which are considered to be master regulators of neuronal phenotype and survival in specific subsets of central and peripheral neurons (Pattyn et al, 1997). Lossof-function mutations indicate that Phox2b and Phox2a are not completely genetic redundant (Brunet and Pattyn, 2002) and exert a complex reciprocal control on their abilities to promote gene transcription.

The current hypothesis concerning these two paralogs is that during development, Phox $2 a$ and $P h o x 2 b$ genes are expressed to different degrees, and the balance between Phox2a and Phox $2 \mathrm{~b}$ proteins determines which genetic pattern is expressed in a given cell, and as such its fate (Brunet and Pattyn, 2002). This seems to be particularly true in catecholaminergic neurons, where Phox2 proteins are competing for expression of the gene encoding dopamine- $\beta$-hydroxylase (Kim et al., 1998; Yang et al., 1998). Phox2a participates in the differentiation of catecholaminergic neurons in restricted areas. Gene inactivation studies show that Phox2a controls development of the nucleus locus coeruleusand the distal sensory ganglia of the ninth and tenth cranial nerves in mice. These structures mediate major regulations of breathing parameters (Katz and Black, 1986, Erickson et al., 1996, Mortola 2001), control breathing frequency (Hilaire et al., 2004, Li and Nattie, 2006) and may control breathing amplitude in rodents. While a homozygous suppression of Phox2a affects both central control of breathing and peripheral reflexes, this mutation is lethal at birth and as such little is known about respiratory insufficiencies resulting from such modifications. In this study, we investigated the breathing behaviour and developmental defects induced by a Phox2a haploinsufficiency in mice, a non-lethal mutation. We observed that Phox $2 \mathrm{a}^{+/-}$ animals show an increased inspiratory volume during normoxia and in response to hypoxic challenges and a delayed maturation of inspiratory duration. We suspect that this respiratory anomaly involves altered petrosal reflexes rather than central deficits, because the mutation is correlated with specific enlargement of the population of chemoafferent cells in this sensory peripheral structure. 


\section{Methods}

All experiments were performed in accordance with ethical guidelines defined by the French Agricultural Ministry and the EU Council Directive for the Care and Use of Laboratory Animals (\#2889).

\section{Mouse genotyping}

Phox2a ${ }^{+/-}$deficient mice (Pattyn et al., 1997) were obtained from JF Brunet and C. Goridis (ENS, Paris). The insertion of a neo cassette, a genetic sequence coding for the expression of neomycin, into the transgene allowed us to distinguish wild type locus from the mutant one. To this end, we performed two sets of PCR, one using a pair of probes specific for Phox2a sequence (sigma proligo) and the other using a pair of probes specific for the neo cassette sequence (sigma proligo). To verify the genetic status of mice, we extracted DNA from tail samples of the animals. The PCR products corresponding to each animal were visualized by gel electrophoresis using a $1.5 \%$ agarose gel in a Tris Acetate EDTA buffer (TAE, chemicon).

Plethysmographic recordings

Breathing patterns were studied in newborn mice from postnatal day 0 (P0) up to postnatal day 10 (P10). For P0 experiments we recorded ventilation in the first hour after birth 6, 12 and 18 hours later. P0 results are an averaged ventilation of these 4 measures for each animal. At P10, all mice were sacrificed for histological examination. Respiratory activity was measured by a barometric method, whole-body plethysmography (Schweitzer et al, 1990) using one recording chamber where the animals were placed in, a reference chamber and a differential pressure transducer. The plethysmograph chambers were of $20 \mathrm{~mL}$ and the pressure difference between the two chambers was measured with the differential pressure transducer (Validyne DP 103-14) connected to a sine wave carrier demodulator (Validyne, CD15). After demodulation, the analog signal from the transducer was amplified, filtered, passed through an analog-to-digital converter (Labmaster TL-1, sampling frequency $1 \mathrm{kHz}$ ) and then captured and stored on disk. Plethysmograms were calibrated during each recording session by injecting 2.5-5 $\mu \mathrm{l}$ of air in the chamber with a Hamilton syringe. During quiet breathing, a computer-assisted method was used to measure breathing amplitude (tidal volume, $\mathrm{V}_{\mathrm{T}}$ ) the durations of inspiration $(\mathrm{Ti})$ and expiration $(\mathrm{Te})$ from which respiratory frequency (f) is derived (Jacquin et al., 1996, Dominguez et al., 2001, Chatonnet et al., 2002, 2003). Temperature was maintained constant (mean $\pm S E=31.1 \pm 0.25^{\circ} \mathrm{C}$ ). As the tidal volume depends of body weight, we divided $\mathrm{V}_{\mathrm{T}}$ by body mass to normalize our results. The total volume of air breathed $(\mathrm{Vm})$ is given by the relation: $\mathrm{Vm}=\mathrm{V}_{\mathrm{T}} \times \mathrm{f}$. Breathing pauses lasting more than 1.5 seconds were considered as apneas and were not included in frequency evaluation. Barometric pressure was measured before each recording session to normalize our results.

In all neonates we measured oral temperature before and after each recording session, the time required to right themselves after being layed on their backs, motility corresponding to the duration of limb, neck or body movements in the plethsmographic chamber and the number of jaw openings following peribuccal contact. 
Hypoxic tests:

We also studied chemoafferent reflexs in $P h o x 2 a^{+/}$mice at $\mathrm{P} 10$ using direct plethysmography. Here, the animal's head is isolated from the rest of the body by a thin membrane which divides the recording chamber into two compartments of $20 \mathrm{~mL}$ each. The head of the animal receives a continuous flow of a normoxic air $(500 \mathrm{~mL} / \mathrm{min})$. This flow rate had no visible effect on the animal's behaviour. Given the flow rate and the volume of the chamber, the calculated time constant for filling the chamber was $2.4 \mathrm{~s}$. The second compartment, containing the body, is the recording chamber. To start the hypoxic challenge, we switched from the normoxic air to a hypoxic mixture $\left(12 \% \mathrm{O}_{2}\right)$ without modifying the flow rate. This technique allowed us to flush the normoxic mixture out of the first compartment in less than $4 \mathrm{~s}$. . The hypoxic exposition lasted 90 seconds and then we switched back to normoxic air. These short-term hypoxic challenges have been shown to specifically recruit chemoafferent stimuli conveyed by glossopharyngeal neurons (Neubauer et al., 1990).

\section{Recording of respiratory rhythm in vitro:}

Experiments were performed on brainstem transverse slices obtained from wild type and heterozygous Phox2a mutant animals using an experimental procedure that will only be briefly described here (for details see Thoby-Brisson et al., 2000). Animals were decapitated, the brainstem was rapidly removed from the skull and placed in ice-cold artificial cerebro spinal fluid (aCSF composed of in mM: $128 \mathrm{NaCl}, 8 \mathrm{KCl}, 1.5 \mathrm{CaCl}_{2}, 1 \mathrm{MgSO}_{4}, 24 \mathrm{NaHCO}$, $0.5 \mathrm{Na}_{2} \mathrm{HPO}_{4}, 30$ glucose, $\left.\mathrm{pH}=7.4\right)$ equilibrated with carbogen $\left(95 \% \mathrm{O}_{2}, 5 \% \mathrm{CO}_{2}\right)$. The isolated brainstem was then glued to an agar block, mounted in a vibratome and serially sectionned from rostral to caudal until specific landmarks were reached (inferior olive and nucleus ambiguus). A 450 $\mu$ m-thick slice containing the Pre-Bötzinger complex region was then isolated and placed in the recording chamber maintained at $30{ }^{\circ} \mathrm{C}$ and continuously superfused with oxygenated aCSF. Experiments were executed blindly since the genotype of the mouse was not known at the time of the recording session.

Neuronal population activity was recorded via an extracellular electrode positioned under visual control using an IR-DIC microscope at the surface of the slice in the preBötzinger complex region in which the population of respiratory neurons lies. The signals were amplified (Grass, 7P511), filtered $(3 \mathrm{KHz}, 3 \mathrm{~Hz})$, integrated (Neurolog System), and recorded using the software program Axoclamp 9 (Axon Instruments, Foster city, CA) and a digitizing interface Digidata1322A (Axon Instruments). Integrated population activity from the pre-Bötzinger complex was in phase with integrated inspiratory activity recorded from the hypoglossal nerve (Thoby-Brisson et al., 2000) and was therefore used as a marker for inspiratory population activity.

\section{Immunohistochemistry}

P10 mice were deeply anaesthetized with pentobarbital and intracardially perfused with a $0.15 \mathrm{M}$ phosphate-buffered saline solution (PBS, $\mathrm{pH} 7.4$ ), followed by a $4 \%$ paraformaldehyde solution prepared in PBS. After craniotomy, the brain was removed and the remaining of the head was hemisected along the midline, to isolate lateral parts of the head containing the right or left inner ear and petrosal ganglia. The three samples were then placed overnight at $4{ }^{\circ} \mathrm{C}$ in the $4 \%$ paraformaldehyde solution. They were then rinsed in PBS, infiltrated with PBS containing $30 \%$ sucrose and stored at $4{ }^{\circ} \mathrm{C}$ until used. Serial 20 $\mu \mathrm{m}$-thick sections were cut throughout each structure studied using a cryostat microtome. Parasagittal or coronal sections for A6, parasagittal section for petrosal ganglia were used to evaluate the number of tyrosine hydroxylase positive neurons. Sets of adjacent sections were stained with cresyl violet and for the tyrosine hydroxylase protein (TH). Sections processed for immunochemistry were incubated overnight at room temperature with an antiTH polyclonal antibody (antibody purchased from Jacques Boy, France; 1:1000 in dilution 
buffer (DB): PBS containing $4 \%$ bovine serum albumine), rinsed and then incubated for 2 hours at room temperature with an anti-rabbit antibody coupled either to biotin (Vector; 1:200 in DB) or to rhodamine (Jackson Immunoresearch; 1:200 in DB). Staining using the biotinconjugated antibody was revealed with the elite peroxydas kit (vector) following manufacturer's instructions.

\section{Cell counts and morphometric analysis:}

Cell number was estimated from $20 \mu \mathrm{m}$ thick serial brain or ganglion sections stained with the appropriate coloration. In every slice of brain or ganglion, cells were counted visually using spot camera visualisation system (spot32, RT Slider, diagnostic instruments). In each slice, only cells exhibiting a visible nucleus were counted. No significant differences could be observed when comparing the mean nucleus diameter. The Abercrombie's correction method was then employed to avoid counting any given cell more than once (Abercrombie, 1946).

Statistical analysis

All results obtained from age-matched wild type and mutant animal groups, not necessarily from the same litter, were compared using an ANOVA test and a Bonferroni/Dunn post hoc of ANOVA in each experiment. Significance is given in the figures as follow: * means $p<0.05$, ${ }^{* *}$ means $p<0.01$ and ${ }^{* * *}$ means $p<0.005$. Results are given as mean $+/-$ SEM.

\section{Results}

\section{Breathing pattern of Phox2a $\mathrm{a}^{+/}$mice}

We employed plesthymographic techniques to analyse ventilatory parameters in WT and mutant mice. These results are presented in table 1. Minute ventilation (VM) in Phox $2 a+/-$ mice was significantly higher that in wild type animals at all ages. This was due to an increased breathing amplitude (tidal volume, VT) with no change in frequency (f) (figure 1, table 1). This breathing pattern was visible from birth (postnatal day $0, \mathrm{P} 0$ ) and persisted until P10 (table 1) and even into adulthood (data not shown) suggesting that no complete compensation occurs over time. In wild type animals, inspiratory duration (Ti) decreased by $20 \%$ over the first 5 days of life. Mutant animals also showed this same reduction in Ti with maturation, but this reduction was delayed by 5 days. As such, at P5, Ti in mutant mice was significantly larger (by 17\%) than in wild type animals. We conclude that the Phox2a+/mutation induces an altered inspiratory phenotype characterised by a large VT and delayed maturation of $\mathrm{Ti}$.

We also examined other physiological parameters such as body weight, oral temperature, righting reflexes and suction behaviour in all animals studied. We found no differences between wild type and mutant groups.

\section{Central generation of breathing}

Plethysmogram analyses revealed that Phox2a haploinsufficiency induces no modification in breathing frequency (Fig. 1D). Individual measurements showed that in contrast to VT and Ti, no Phox $2 \mathrm{a}^{+/-}$phenotype can be derived from the analysis of respiratory and suction rhythms suggesting that central pattern generators activity are not affected (Fig.2). We also analysed the duration of expiration (Te, table 1) because low frequency, lethal apneas and irregularities in breathing rhythm could be indicative of altered rythmogenesis. In neonates we did not observe any modification of Te (table 1). Finally, we isolated the respiratory rhythm generator in a transverse brainstem slice (Smith et al., 1991) and recorded the spontaneous rhythmic activity from respiratory neuronal populations (Koshiya et al., 1999; Thoby-Brisson et al., 2000). In accordance with in vivo measurements, the respiratory frequency measured in vitro was normal in mutants $(14.2 \pm 1.4 \mathrm{burst} / \mathrm{min}$ in wild type versus $15.6 \pm 0.6$ in Phox $2 a^{+-}$mutants $n=5$, Fig. $2 A$ ). 


\section{Increased chemoreflex control}

Plethysmographic recording of breathing under hypoxic conditions were performed on young neonates at postnatal day P10. During a $90 \mathrm{~s}$ exposure to a hypoxic mixture containing $12 \%$ oxygen (Fig. $3 \mathrm{~A}$ ), the tidal volume and frequency were first increased within 10 s of hypoxia, and decreased afterward. At the end of the hypoxic challenge, the ventilatory depression persisted during 60s, after which the animals recovered control respiratory parameters (Table 2, Fig. 3B). Short-term (10 s) responses to hypoxic challenge indicated that chemoafferent inputs to the rhythm generator were active in $P$ hox $2 \mathrm{a}^{+-}$mice and caused an increase in VT induced by hypoxia were larger than normal in Phox $2 a^{+/-}$mice (Fig 3B, upper part). WT and Phox $2 \mathrm{a}^{+/-}$mice had the same chemosensitivity, measured by reporting VT during hypoxia to VT in normoxia (expressed in percentage of increase in Table 2). . During long term hypoxic depression where chemoafferences are progressively inhibited, Phox $2 \mathrm{a}^{+/-}$and wild-type VT were not significantly different because of a higher depression occurring in Phox $2 \mathrm{a}^{+-}$mice, suggesting that central structures controlling breathing are not affected by the mutation (table2, Fig. 3B upper part). The two types of animals were indistinguishable from their frequency (Table2, Fig.3B lower part).

\section{Anatomical studies of Phox $2 a^{+/-}$mice}

We analysed the anatomical properties of neural structures that were found to be affected by the homozygous mutation of the Phox2a gene and in particular the petrosal sensory ganglion and the locus coeruleus.

The petrosal ganglion contains about 1400 cell bodies among which $10 \%$ are dopaminergic chemoafferent neurons expressing tyrosine-hydroxylase (Katz and Black, 1986, Hellard et al., 2004) which are eliminated in Phox2a ${ }^{-/-}$mutants (Pattyn et al., 1997). We compared the number of TH positive PG neurons in newborn wild-type and mutant animals to see the effect of phox2a haploinsufficiency on the specification of chemoafferent neurons (Fig. 4A). In Phox $2 \mathrm{a}^{+-}$mice the number of TH positive neurons per ganglion was dramatically increased compared to wild-type controls (Fig. 4C, $144 \pm 17$ in wild-type, $n=16$ vs $313 \pm 7$ in Phox2a ${ }^{+/-}$mice, $n=16$ ). However, the total number of $P G$ neurons (Fig. 4B, 1141 \pm 106 neurons in wild-type, $n=16$ vs $1070 \pm 48$ in Phox $2 a^{+/-}, n=16$ ) was not significantly different in

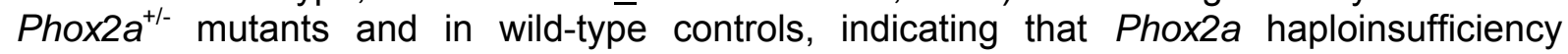
resulted in a specific increase in the number of cells expressing $\mathrm{TH}$. By expressing the number of $\mathrm{TH}+$ cells as a function of tidal volume (Fig 4E), we can see that mice exhibiting the higher values of $V_{T}$ also have the highest number of chemoafferent cells.

To determine whether or not Phox2a haploinsufficiency also increased TH expression in central catecholaminergic cell groups, we examined TH cell number in the pontine noradrenergic group A6, the nucleus locus coeruleus. This structure contains between 1200 and $1600 \mathrm{TH}$ positive neurons grouped into three subdivisions, the locus proper, the rostral and ventral subcoeruleus extensions (Swanson, 1976; Bezin et al., 1994; Von Coelln et al, 2004). Using immunohistochemistry, the general cell morphology, the location and the size of the subdivisions were found normal in mutants' brains examined in coronal $(n=4)$ or parasagittal $(n=5)$ planes (Fig. 5A). Unlike the petrosal ganglion, number of TH positive cells was not significantly different in the locus coeruleus of $P$ hox $2 \mathrm{a}^{+-}$mutants $(1141 \pm 106$ neurons in wildtype, $n=9$ vs $1070 \pm 48$ in Phox $2 a^{+-}, n=9$; Fig. 5B). The location and the shape of locus coeruleus cells were not affected by the mutation and the average soma diameter was not significantly different from control animals $(15.9 \pm 0.6 \mu \mathrm{m}$ in wild type versus $16.0 \pm 0.7 \mu \mathrm{m}$ in mutant group). Taken together, anatomical data support the existence of anomalies in the reflex control of inspiration, rather than a central effect mediated by pontine catecholaminergic nuclei in Phox $2 \mathrm{a}^{+/-}$mice. 


\section{Discussion}

The present study describes a Phox $2 \mathrm{a}^{+/-}$breathing phenotype characterized by a large $\mathrm{V}_{\mathrm{T}}$ and a delayed postnatal maturation of $\mathrm{Ti}$. These breathing alterations are associated with an increase in the number of chemoafferent neurons in the petrosal ganglia, while $\mathrm{TH}$ expressing neurons in the central nucleus locus coeruleus are unaffected. Interestingly breathing frequency was not modulated by the mutation suggesting that central structures controlling breathing rhythm are not affected. As such, because in Phox $2 a^{+/-}$mice the $V_{T}$ is increased more than normally during the early phase of hypoxia and is correlated with the numbre of chemoafferent neurons, we conclude that this mutation affects the reflex control of inspiration.

\section{Phox2a haploinsufficiency does not affect central respiratory-related structures}

Phox $2 \mathrm{a}^{+/}$mice were found to hyperventilate, exhibiting a larger-than-normal average volume of air breathed $(\mathrm{Vm})$ at all ages studied. Hyperventilation results from an abnormality in the inspiratory phase. Genetically-transmitted low respiratory frequency, neonatal apneas and rhythm irregularity are induced by other mutations and are associated with an abnormal development of the brainstem rythm generators (Jacquin et al., 1996, Shirasawa et al., 2000, Dominguez et al., 2001, Chatonnet et al., 2002, 2003, Blanchi et al., 2003, Viemari et al., 2004, 2005, Durand et al., 2005). These animals die shortly after birth. In some cases such mutations are associated with abnormal suction behaviour (Jacquin et al., 1996). Lethal apneas and other phenotypic traits pointing to dysfunction of the central pattern generators are not observed in Phox2a haploinsufficient animals, as such it is unlikely that the central rhythm generation is significantly affected. Furthermore, in contrast to Phox $2 a^{+/}$mutation, mutations affecting the maturation of the bulbar respiratory generator abnormal breathing frequency observable after isolation in vitro (Jacquin et al., 1996, Shirasawa et al., 2000, Dominguez et al., 2001, Chatonnet et al., 2002, 2003, Blanchi et al., 2003, Viemari et al., 2004, 2005, Durand et al., 2005). Breathing deficits described in Phox2a ${ }^{+-}$mutants are distinct from those so far identified after the inactivation of genes controlling development of brainstem central pattern generators in the brainstem. In addition, breathing during the delayed responses to hypoxia is mediated by central chemosensory mechanisms as chemoafferences are progressively inhibited (Neubauer et al., 1990, Dillon et al., 1991, Oyama et al., 1998, Chatonnet et al., 2002, Li and Nattie, 2006). Those mechanisms appear normal and functional in these mutants although it would be interesting to further compare the central chemosensitivity using in vitro preparations.

The central control of rhythm generation was normal, as well as other behavioural and physiological parameters studied, including neonatal and long-term survival, body weight, righting and jaw opening reflexes, mobility and oral temperature (data not shown). Thus, the abnormal breathing pattern exhibited by Phox $2 \mathrm{a}^{+-}$mice is compatible with normal behavioural development and survival and does not appear to be indicative of acute respiratory distress. The Phox2a haploinsufficiency syndrome may therefore target respiratory controls operating outside the central control of breathing, in particular the reflex control of breathing.

\section{TH expression in the Phox $2 \mathrm{a}^{+/-}$locus coeruleus}

Previous results on homozygous mutants demonstrate that Phox $2 a$ is required for the correct establishment and functional development of the nucleus locus coeruleus (Viemari et al., 2004). This pontine noradrenergic structure provides a tonic excitatory drive that contributes to a normal breathing rate in rats (Guyenet et al., 1993; Jodkowski et al., 1997; Oyama et al., 1998; Dawid-Milner, et al., 2001; Li and Nattie, 2006) and mice (Shirasawa et al., 2000; Hilaire et al., 2004). Elimination of the locus coeruleus is linked to a severe decrease in the respiratory frequency of homozygous Phox $2 a^{-1-}$ mutants (Viemari, et al., 2004, Li and Nattie, 2006). Here we show that despite the low expression of the Phox2a protein, locus coeruleus neurons can build a functional pontine catecholaminergic phenotype, since A6 cells are normal in shape, size and anatomical location, and since breathing rhythm is normal. 


\section{Phox2a dose-dependent regulation of the sensory neuronal fate}

The present study shows that Phox2a has a dose-dependent influence on the development of TH positive cells in the petrosal ganglion. During embryonic development (E10.5-13.5), many petrosal and nodose sensory neurons transiently express $\mathrm{TH}$ and dopamine- $\beta$-hydroxylase $(\mathrm{DBH})$ and then switch to a non-catecholaminergic phenotype before a subset of ganglion cells begins to accumulate TH (Jonakait et al, 1984). Both the early, transient phase of noradrenergic expression and the late, stable phase of dopaminergic expression are associated with co-expression of Phox2a and Phox $2 b$ transcription factors (Pattyn, et al. 1997; Brosenitsch and Katz, 2005, 2002). Transient expression of $\mathrm{DBH}$ by petrosal and nodose neurons requires Phox2a expression and is absent in Phox2a null mutant mice (Pattyn, et al. 1997). However, homozygous mutants provide no information on later stages because the ganglia degenerate soon after. We presently show that the proportion of $\mathrm{TH}$ positive petrosal neurons increases in Phox $2 \mathrm{a}^{+/}$ mutants withno change in ganglion cell number. This indicates a specific role of Phox $2 a$ in the phenotypic specification of catecholaminergic neuron progenitors.

\section{Phox2a dose-dependent involvement during development of inspiratory controls}

Increased tidal volume in Phox $2 a^{+/-}$mutants suggests that Phox2a controls specific neuronal circuits controlling breathing. Tidal volume is protected during changing behavioural demands by reflex compensation against mechanical loads (Mortola, 2001). Vagal reflexes, mediated by pulmonary stretch receptors controlling $\mathrm{Ti}$, are the core mechanisms for immediate load compensation, particularly in newborns, so that vagotomy results in deeper breathing in the newborn than in the adult. When mechanical loads are sustained, the maintain of tidal volume and ventilation also involves chemoreflexes (LaFramboise et al. 1983, Rigatto et al., 1988, Duara et al., 1991, 1993). We hypothesize that the exaggeration of VT and the delayed maturation of Ti observed in Phox $2 \mathrm{a}^{++-}$mice results from the elevated number of dopaminergic chemoafferent neurons. Current hypothesis propose that chemoafferent fibres may act presynaptically on vagal afferent fibres (underlying the Hering Breuer reflex) coming from stretch receptors (Kline et al.,2002) and may modulate mechanical load compensation. Therefore, the possibility that this phenotype might result from yet undetected dysfunction of stretch receptor afferents in the nodose ganglion cannot be excluded. Furthermore Phox2a is also essential for development of the superior cervical ganglion. The superior cervical ganglion provides a major sympathetic input to the carotid body and the noradrenergic input is able to modify the chemosensory afferent pathway. We cannot exclude that the changes observed here in hypoxic ventilatory response are in part dependent on defects in sympathetic nerve activity.

Our finding that the Phox $2 \mathrm{a}^{+/-}$mutation affects both the number of TH positive PG neurons and tidal volume supports the hypothesis that Phox2a signalling influences development of load compensation by regulating the number of chemoafferent cells. The fact that $\mathrm{V}_{\mathrm{T}}$ is increased in newborn Phox $2 \mathrm{a}^{+/-}$mice under all conditions examined, i.e. during room air breathing and during the hypoxic response, indicates that synaptic mechanisms that normally restrict $V_{T}$ are diminished in these animals while chemosensitivity itself is not affected. There are now several mutants or experimental models that testify to a relationship between chemoafferent cell number in the petrosal ganglion and tidal volume. For example, in Phox $2 b$ heterozygote mutants, a reduced number of chemoafferent neurons is associated with a blunting of the normal increase in VT in response to hypoxic stimuli (Dauger et al., 2003). Similarly, a reduction in chemoafferent neurons is associated with a decreased tidal volume in heterozygous and homozygous BDNF mutants (Erickson, et al., 1996). These results are in accordance with the hypothesis that chemoafferent signalling is a regulatory pathway of breathing amplitude. 


\section{Conclusion}

The present study shows that the number of Phox2a alleles influences the breathing behaviour and the fate of petrosal neurons. By interrupting several genetic signalling pathways, complete Phox2a inactivation produces various defects including depression of the central respiratory generator and elimination of locus coeruleus and sensory afferent neurons. Nevertheless, the heterozygous mutation of Phox $2 a$ is linked to a more specific phenotype, that of a delayed maturation of inspiratory duration and an increased tidal volume during normoxic and hypoxic breathing, correlated with an increase in the number of chemoafferent neurons. These results identify a higly selective dose-dependent function of Phox2a in specifying petrosal neuronal types during development. This study also provides new insight into understanding how tidal volume and maturation of inspiratory duration can be affected in human syndromes presenting a deregulation of breathing amplitude.

\section{Acknowledgements}

This work was supported by grants coming from the "Centre National pour la Recherche Scientifique » (CNRS) and the European Community (QLG2/CT/2001-01467). Ludovic J Wrobel was awarded by the French " Ministère de la Recherche ». Jean-François Brunet, Christo Goridis and Cyril Ribeyre are gratefully acknowledged for discussions around the article. Christelle Thaeron is acknowledged for her participation in preliminary experiments.

\section{References}

Amiel J, Laudier B, Attie-Bitach $T$, Trang H, de Pontual L, Gener B, Trochet D, Etchevers $H$, Ray P, Simonneau M, Vekemans M, Munnich A, Gaultier C, Lyonnet S (2003)

Polyalanine expansion and frameshift mutations of the paired-like homeobox gene PHOX2B in congenital central hypoventilation syndrome. Nat Genet 33: 459-461

Bezin L, Marcel D, Debure LI, Ginovart N, Rousset C, Pujol JF, Weissmann D. (1994)

Postna tal development of the tyrosine hydroxylase-containing cell population within the rat locus coeruleus: topological organization and phenotypic plasticity. J. Neurosci 14: 7486-7501.

Bianchi AL, Denavit-Saubie M, Champagnat J. (1995) Central control of breathing in mammals: neuronal circuitry, membrane properties, and neurotransmitters. Physiol Rev 75: 1-45.

Blanchi B, Kelly LM, Viemari JC, Lafon I, Burnet $H$, Bevengut M, Tillmanns S, Daniel L, Graf T, Hilaire $G$, Sieweke MH (2003) MafB deficiency causes defective respiratory rhythmogenesis and fatal central apnea at birth. Nat Neurosci 6:1091-100.

Brosenitsch TA, Katz DM. (2005) Physiological patterns of electrical stimulation can induce neuronal gene expression by activating N-type calcium channels. J Neurosci 21:2571-9.

Brosenitsch TA, Katz DM (2002) Expression of Phox2 transcription factors and induction of the dopaminergic phenotype in primary sensory neurons. Mol Cell Neurosci 20:447-57.

Brunet JF, Pattyn A. (2002) Phox2 genes - from patterning to connectivity. Curr Opin Genet Dev. 12: 435-40.

Chatonnet F, Boudinot E, Chatonnet A, Taysse L, Daulon S, Champagnat J, Foutz AS (2003)

Respiratory survival mechanisms in acetylcholinesterase knockout mouse. Eur J Neurosci 18: 1419-

1427.

Chatonnet F, Domínguez del Toro E, Thoby-Brisson M, Champagnat J, Fortin G, Rijli FM ThaëronAntôno C (2003) From hindbrain segmentation to breathing after birth, developmental patterning in rhombomeres 3 and 4, Molecular Neurobiology 28: 277-293.

Chatonnet, F;, Dominguez del Toro, E, Voilescu, O., Charnay, P. Champagnat, J (2002) Different respiratory control systems are affected in homozygous and heterozygous kreisler mutant mice European Journal of Neuroscience 15: 684-692.

Dauger S, Pattyn A, Lofaso F, Gaultier C, Goridis C, Gallego J, Brunet JF (2003) Phox2b controls the development of peripheral chemoreceptors and afferent visceral pathways. Development 130:66356642.

Dawid-Milner M, Lara J, Gonzales-Baron S, Spyer K (2001) Respiratory effects of stimulation of cell bodies of the A5 region in anesthetized rats. Pflüg. Arch. 441: 434-443. 
De Pontual L, Nepote V, Attie-Bitach T, Al Halabiah H, Trang H, Elghouzzi V, Levacher B, Benihoud K, Auge J, Faure C, Laudier B, Vekemans M, Munnich A, Perricaudet M, Guillemot F, Gaultier C, Lyonnet S, Simonneau M, Amiel J. (2003). Noradrenergic neuronal development is impaired by mutation of the proneural MASH-1 gene in congenital central hypoventilation syndrome (Ondine's curse). Hum Mol Genet. 12(23),3173-3180

Dillon, G.H., Welsh, D.E., and Waldrop, T.G. (1991). Ventrolateral pons mediates short-term depression of respiratory frequency after brief hypoxia. Respir. Physiol. 121, 87-100.

Dominguez del Toro E, Borday V, Davenne M, Neun R, Rijli FM, Champagnat J (2001) Generation of a novel functional neuronal circuit in Hoxa1 mutant mice. J Neurosci 21: 5637-5642.

Duara S, Neto GS, Gerhardt T, Suguihara C, Bancalari E (1991) Metabolic and respiratory effects of flow-resistive loading in preterm infants. J Appl Physiol 70: 895-899.

Duara S, Suguihara C, Gerhardt T, Bancalari E (1993) Metabolic, hemodynamic, and ventilatory responses to respiratory load in sedated neonatal piglets. J. Appl. Physiol 75: 181-184.

Durand E, Dauger S, Pattyn A, Gaultier C, Goridis C, Gallego J (2005) Sleep-disordered breathing in newborn mice heterozygous for the transcription factor Phox2b. Am J Respir Crit Care Med 172: 238243.

Erickson JT, Conover JC, Borday V, Champagnat J, Barbacid M, Yancopoulos G, Katz DM (1996) Mice lacking brain-derived neurotrophic factor exhibit visceral sensory neuron losses distinct from mice lacking NT4 and display a severe developmental deficit in control of breathing. J Neurosci 16: 5361-5371.

Feldman JL, Del Negro CA. (2006) Looking for inspiration: new perspectives on respiratory rhythm. Nat Rev Neurosci. 7(3):232-42.

Guyenet PG, Koshiya N, Huangfu D, Verberne AJ, Riley TA (1993) Central respiratory control of A5 and A6 pontine noradrenergic neurons. Am. J. Physiol. Regul. Integrative Comp. Physiol. 264: R1035R1044.

Hellard D, Brosenitsch T, Fritzsch B, Katz DM (2004) Cranial sensory neuron development in the absence of brain-derived neurotrophic factor in BDNF/Bax double null mice. Dev. Biol. 275: 34-43. Hilaire G, Duron B (1999) Maturation of the mammalian respiratory system. Physiol Rev.

Apr;79(2):325-60

Hilaire G, Viemari JC, Coulon P, Simonneau M, Bevengut M. (2004) Modulation of the respiratory rhythm generator by the pontine noradrenergic A5 and A6 groups in rodents. Respir Physiol Neurobiol. 143(2-3):187-97.

Jacquin TD, Borday V, Schneider-Maunoury S, Topilko P, Ghilini G, Kato F, Charnay P, Champagnat $\mathrm{J}$ (1996) Reorganization of pontine rhythmogenic neuronal networks in Krox-20 knockout mice. Neuron 17: 747-758.

Jodkowski JS, Cole SK, Dick TE (1997) Prolongation in expiration evoked from ventrolateral pons of adult rats. J. Appl. Physiol. 82: 377-381.

Jonakait GM, Markey KA, Goldstein M, Black IB (1984) Transient expression of selected catecholaminergic traits in cranial sensory and dorsal root ganglia of the embryonic rat. Dev Biol 101: 51-60.

Katz DM, Black IB(1986) Expression and regulation of catecholaminergic traits in primary sensory neurons: relationship to target innervation in vivo. J Neurosci 6:983-989.

Kim HS, Seo H, Yang C, Brunet JF, Kim KS (1998) Noradrenergic-specific transcription of the dopamine beta-hydroxylase gene requires synergy of multiple cis-acting elements including at least two Phox2a-binding sites. J Neurosci 18: 8247-8260.

Kline DD, Takacs KN, Ficker E, Kunze DL (2002) Dopamine modulates synaptic transmission in the nucleus of the solitary tract. Jneurophysiol 88(5):2736-44.

Koshiya N, Smith JC (1999) Neuronal pacemaker for breathing visualized in vitro. Nature 400: 360363.

LaFramboise WA, Tuck RE, Standaert TA, Woodrum DE (1983) An elastic loading system for ventilatory studies in small animals. J Appl Physiol 54: 314-317

$\mathrm{Li} A$, Nattie $E$ (2006) Catecholamine neurones in rats modulate sleep, breathing, central chemoreception and breathing variability. J. Physiol. Lond. 570: 385-396.

Mortola, J.P (2001) Respiratory physiology of newborn mammals, a comparative perspective.

The John Hopkins University Press

Neubauer, J.A., Melton, J.E., Edelman, N.H. (1990) Modulation of respiration during brain hypoxia. J. Appl. Physiol. 68 : 441-451.

Onimaru H, Homma I. (2003) A novel functional neuron group for respiratory rhythm generation in the ventral medulla. J Neurosci. 23(4):1478-86. 
Oyama Y, Ballantyne D, Mückenhoff K, Scheid P (1998) Respiration-modulated membrane potential and chemosensitivity of locus coeruleus neurones in the in vitro brainstem-spinal cord of the neonatal rat. J. Physiol. Lond. 513: 381-398.

Pascual O, Morin-Surun MP, Barna B, Denavit-Saubie M, Pequignot JM, Champagnat J (2002)

Progesterone reverses the neuronal responses to hypoxia in rat nucleus tractus solitarius in vitro. $\mathrm{J}$ Physiol Lond. 544: 511-520

Pattyn A, Morin X, Cremer H, Goridis C, Brunet JF (1997) Expression and interactions of the two closely related homeobox genes Phox2a and Phox2b during neurogenesis. Development 124: 40654075.

Richter DW, Spyer KM. (2001) Studying rhythmogenesis of breathing: comparison of in vivo and in vitro models. Trends Neurosci. Aug;24(8):464-72.

Rigatto $H$, Wiebe C, Rigatto C, Lee DS Cates D (1998) Ventilatory response to hypoxia in unanesthetized newborn kittens. J. Appl. Physiol 64: 2544-2551.

Roux JC, Peyronnet J, Pascual O, Dalmaz Y, Pequignot JM (2000) Ventilatory and central

neurochemical reorganisation of $\mathrm{O} 2$ chemoreflex after carotid sinus nerve transection in rat. J. Physiol. Lond. 522: 493-501.

Shirasawa S, Arata A, Onimaru H, Roth KA, Brown GA, Horning S, Arata S, Okumura K, Sasazuki T, Korsmeyer SJ. (2000) Rnx deficiency results in congenital central hypoventilation. Nat Genet (3):28790.

Smith JC, Ellenberger HH, Ballanyi K, Richter DW, Feldman JL (1991) Pre-Botzinger complex: a brainstem region that may generate respiratory rhythm in mammals. Science 254: 726-729.

Swanson LW (1976) The locus coeruleus: a cytoarchitectonic, Golgi and immunohistochemical study in the albino rat. Brain Res 110: 39-56.

Thoby-Brisson M, Ramirez JM (2000) Role of inspiratory pacemaker neurons in mediating the hypoxic response of the respiratory network in vitro. J Neurosci 20: 5858-5866.

Viemari JC, Bevengut M, Burnet $H$, Coulon P, Pequignot JM, Tiveron MC, Hilaire G (2004) Phox2a gene, A6 neurons, and noradrenaline are essential for development of normal respiratory rhythm in mice J. Neurosci. 28: 928-937.

Viemari JC, Maussion G, Bevengut M, Burnet H, Pequignot JM, Nepote V, Pacnis V, Simmonneau M, Hilaire $G$ (2005) Ret deficiency in mice impairs the development of $A 5$ and A6 neurons and the functional maturation of the respiratory rhythm Eur. J. Neurosci 22: 2403-2412.

Von Coelln R, Thomas B, Savitt JM, Lim KL, Sasaki M, Hess EJ, Dawson VL, Dawson TM (2004) Loss of locus coeruleus neurons and reduced startle in parkin null mice. Proc Natl Acad Sci U S A 101:10744-10749.

White FA, Keller-Peck CR, Knudson CM, Korsmeyer SJ, Snider WD (1998) Widespread elimination of naturally occurring neuronal death in Bax-deficient mice. J Neurosci 18:1428-1439.

Yang C, Kim HS, Seo H, Kim CH, Brunet JF, Kim KS (1998) Paired-like homeodomain proteins, Phox2a and Phox2b, are responsible for noradrenergic cell-specific transcription of the dopamine beta-hydroxylase gene. J. Neurochem. 71: 1813-1826. 


\section{FIGURE LEGENDS}

Figure 1:
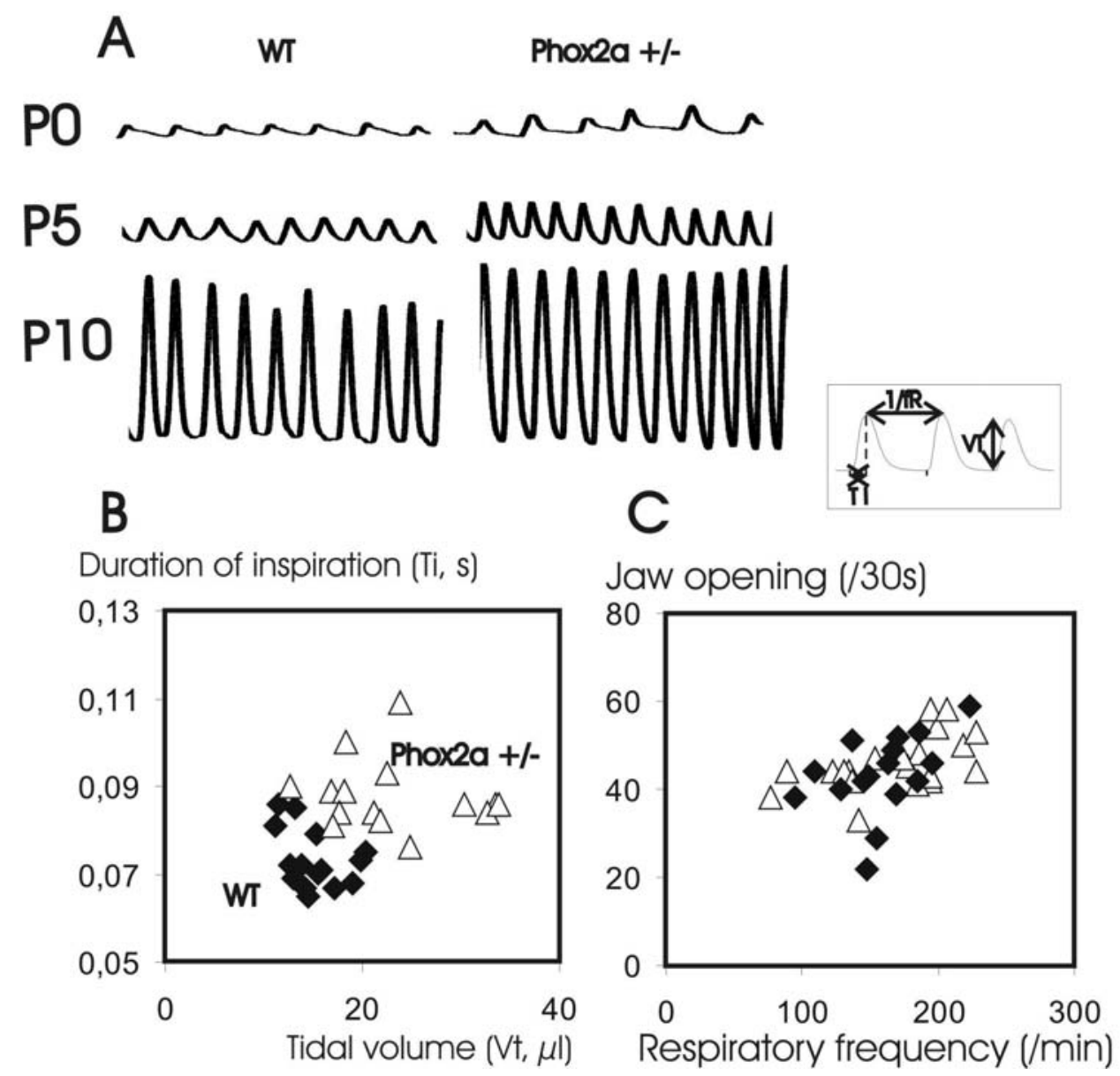

Breathing pattern of $P h o x 2 a^{+-}$mutants during the first post-natal week.

A. Samples of whole body plethysmographic recordings of wild type (left) and Phox $2 \mathrm{a}^{+/}$ (right) animals obtained at age P0 (first postnatal day). Vertical scale bar is $10 \mu \mathrm{l}$; Horizontal scale bar is (1s). B. Diagram illustrating how physiological data are calculated from plethysmograms. $\mathrm{Ti}$ is the inspiratory phase duration $(\mathrm{s}), \mathrm{Te}$ is the expiratory phase duration $(s)$, $f$ is the breathing frequency (cycles per minute), and $V_{T}$ is the tidal volume ( $\mu$ l per gram). C. Diagram showing the evolution of $\mathrm{Vm}(\mu \mathrm{l} / \mathrm{min} / \mathrm{g})$ between age P0 and P10 in wild type mice (black diamonds, $n=15$ ) and $P$ hox $2 a^{+--}$(open triangles; $n=15$ ). D. Evolution of wild type (black diamonds; $n=15$ ) and Phox $2 a^{+/-}$(open triangles; $\left.n=15\right)$ mice breathing frequency (f; cycles/min) in the days following birth. E. Evolution of wild type (black diamonds; $n=15$ ) and Phox $2 a^{+/-}$(open triangles; $n=15$ ) mice tidal volume $\left(V_{T} ; \mu l / g\right)$ in the days following birth. 
Figure 2:
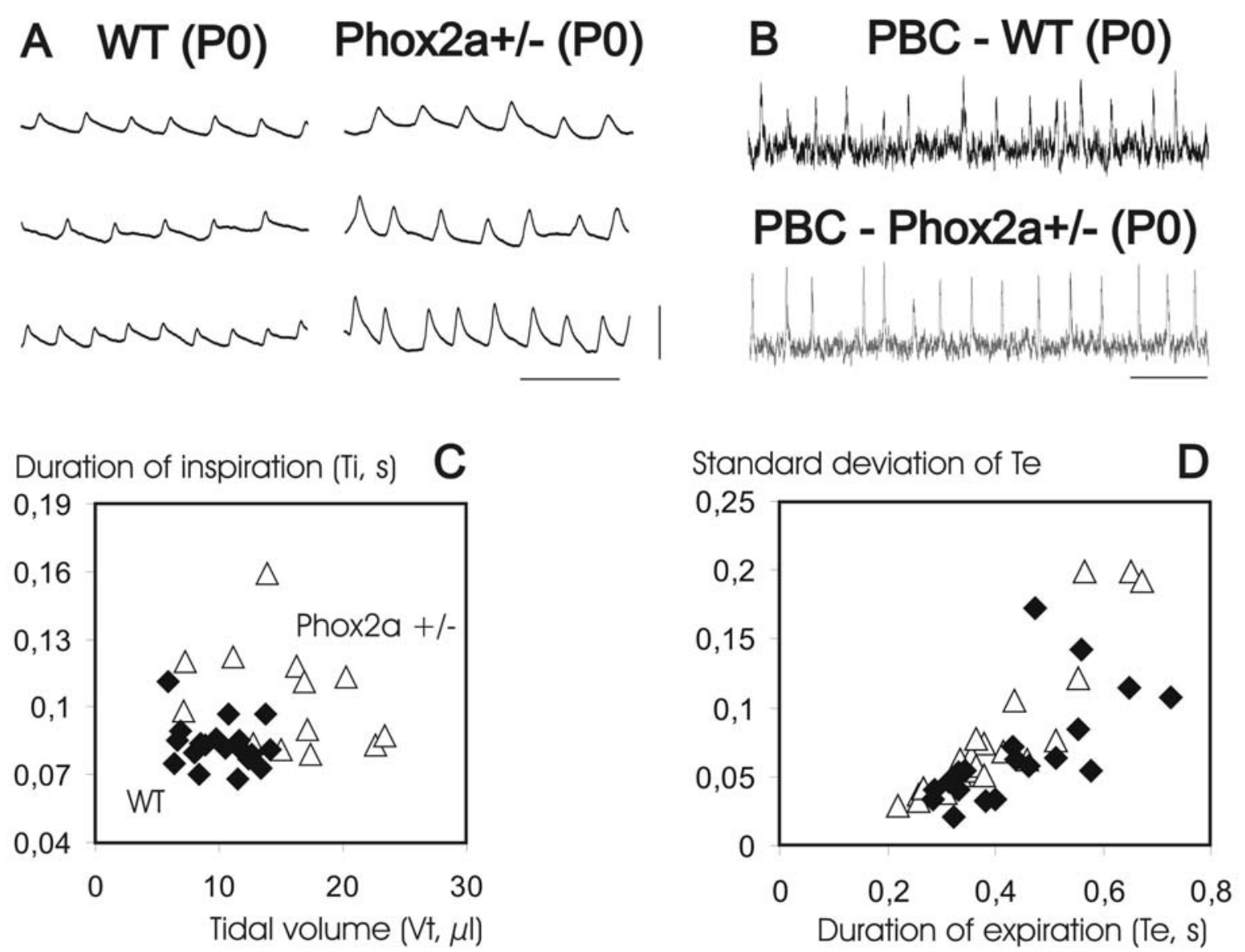

Integrity of frequency control in Phox $2 a^{+/-}$mice.

A. Integrated extra-cellular recordings of Pre-Bötzinger complex in vitro activity in wild type mice (upper trace, $n=5$ ) and Phox $2 a^{+/-}$(lower trace, $\left.n=5\right)$ mice. B. Relationship between the respiratory frequency (f, cycles/min) and rhythmic suction activity (number of jaw openings induced during a 30 s period by tactile stimulations of the buccal cavity) of wild-type (black diamonds; $n=17$ ) and Phox $2 a^{+/-}$(open triangles; $n=20$ ) mice. 


\section{Figure 3:}

A Phox2a +l-

NNNU

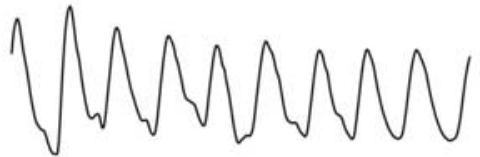

$\wedge \wedge$ Normoxia

C Hypoxic change of $\mathrm{VT} / \mathrm{M}$

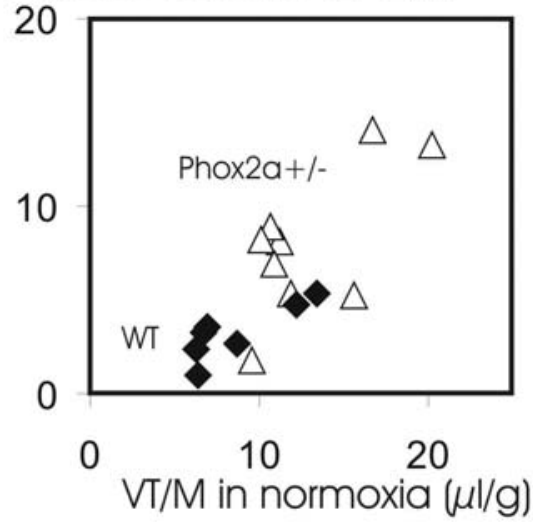

B 20
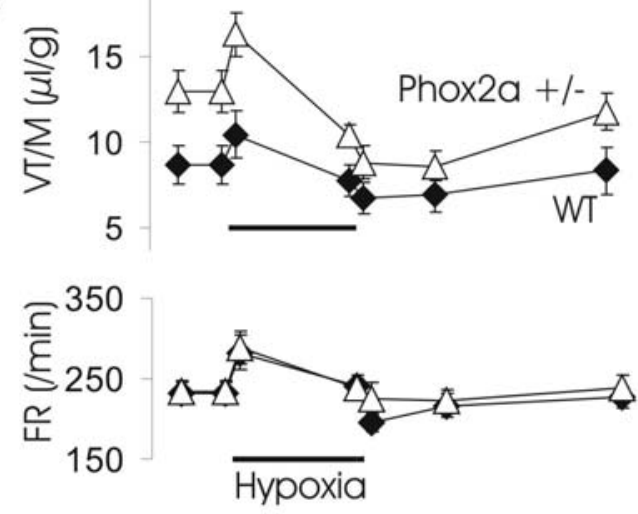

D Hypoxic change of FR

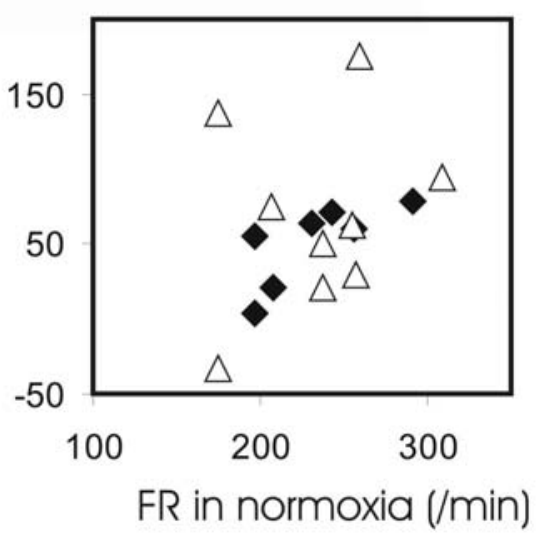

Effect of hypoxia in Phox2a ${ }^{+/}$mutants (P10).

A. Samples of plethysmographic recordings showing the respiratory response of a Phox $2 a^{+/-}$ mutant at the onset (10s), at the end (90s) and after (lower trace) a 12\%O2 hypoxia (scale bar is $10 \mu \mathrm{L}$ ). B. Tidal volume (upper part) and respiratory frequency (lower part) of wild-type (WT, black losanges; $n=10$ ) versus Phox $2 a^{+/-}$(white triangles; $n=10$ ) mice, in control conditions, after $10 \mathrm{~s}$ and $90 \mathrm{~s}$ of hypoxia (bar under tracings), and then $180 \mathrm{~s}$ after switching back to a normoxic air. Hypoxia induces an increase followed by a decrease of both tidal volume and frequency. 
Figure 4: Petrosal catecholaminergic cells in wild type and Phox2a ${ }^{+/-}$mice.
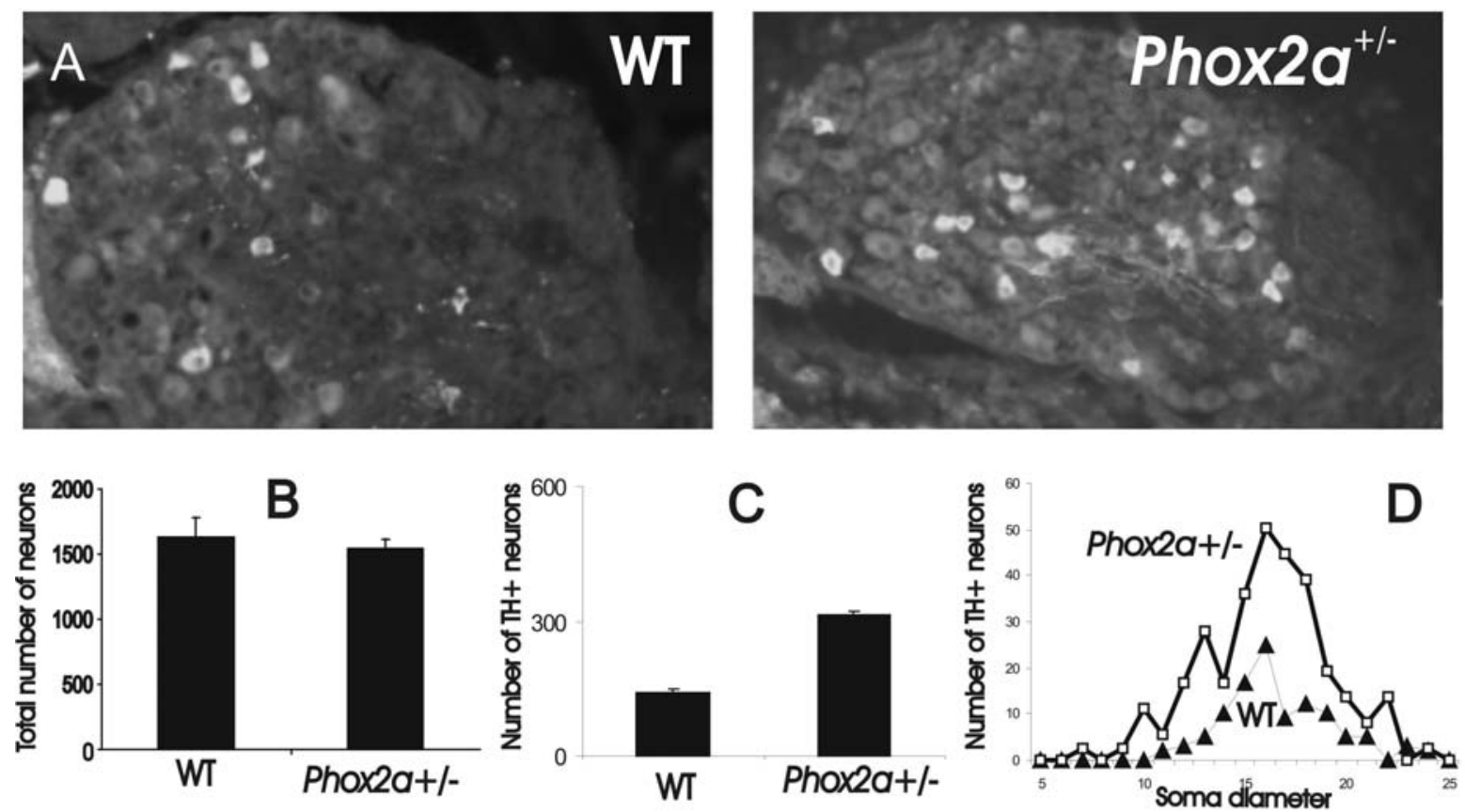

A. Tyrosine hydroxylase immunoreactivity of wild-type (left) and Phox $2 a^{+/-}$(right) ganglia at postnatal day 10. B. Histogram showing the total number of petrosal neurons in wild type (left) and Phox $2 \mathrm{a}^{+/}$(right) ganglia. C. Histogram showing the number of chemoafferent neurons expressing tyrosine hydroxylase in wild type (left) and Phox2a ${ }^{+/-}$(right) ganglia.D. Distribution of soma diameters of $\mathrm{TH}+$ cell bodies in wild type (black diamonds; $\mathrm{n}=5$ ) and Phox2a $\mathrm{a}^{+/-}$(open triangles; $\mathrm{n}=5$ ) ganglia. The population of chemoafferent neurons is larger in

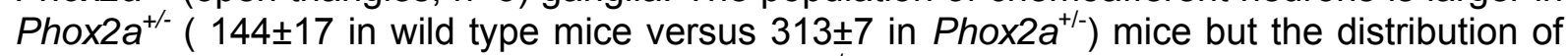
the cell diameter is not changed by the Phox $2 a^{+/-}$mutation. E. Plots of chemoafferent cells' number as a function of tidal volume in wild type (black diamonds) and Phox $2 \mathrm{a}^{+/-}$(open triangles). 


\section{Figure 5:}

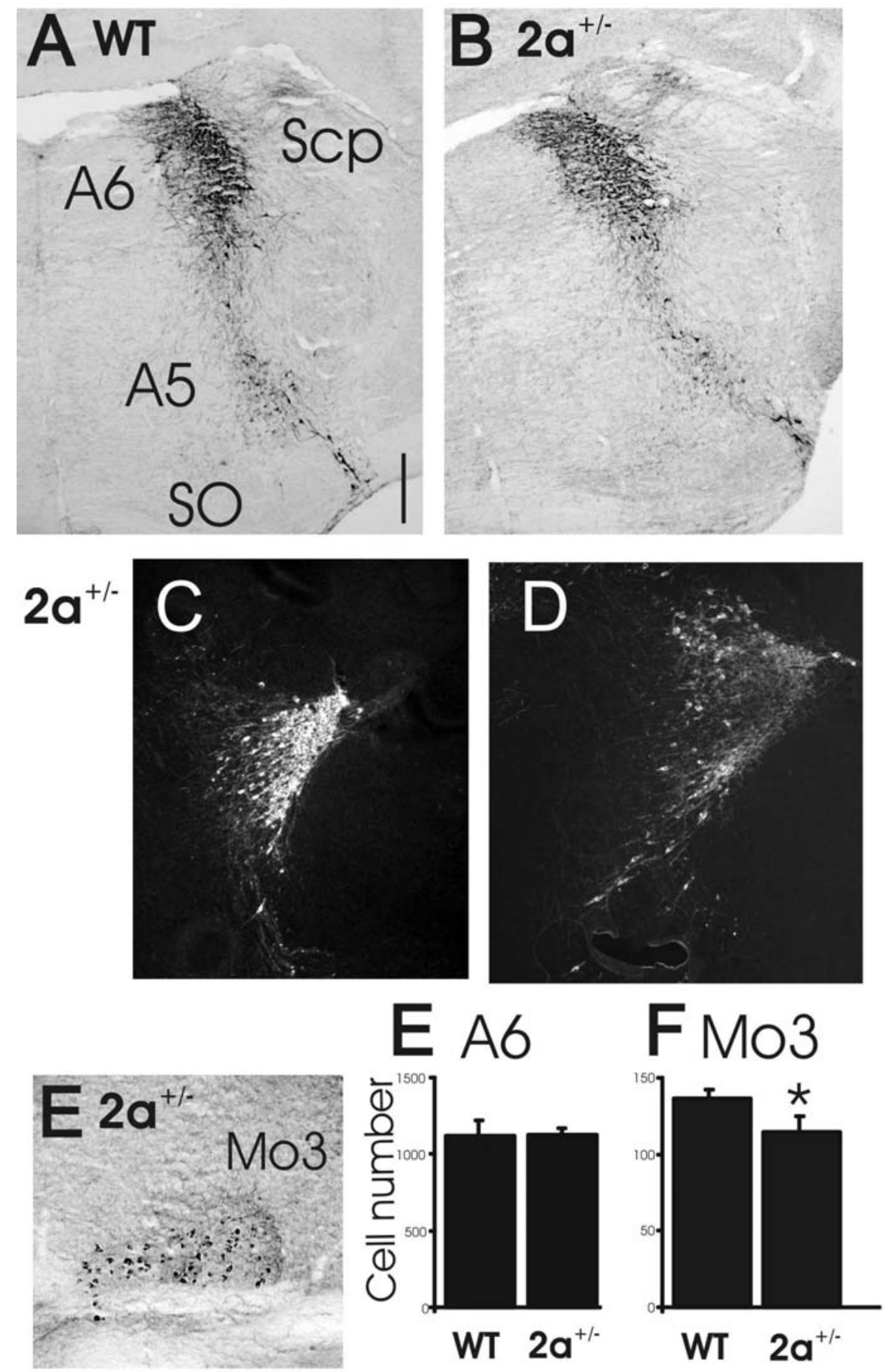

Anatomy of the Phox $2 a^{+l-}$ locus coeruleus

A. Tyrosine hydroxylase immunoreactivity in wild-type (left) and mutant (right) coronal brainstem sections showing locus coeruleus (A6). (Scale bar is: $200 \mu \mathrm{m}$ ). B. Number of cells expressing tyrosine hydroxylase in the locus coeruleus in wild type (left; $n=9$ ) and Phox $2 \mathrm{a}^{+/-}$ mutant (right; $n=9$ ) mice. 